\title{
Variations in Serum Concentrations of Lead, Copper, Zinc and Selenium in Women Practicing Different Contraceptive Methods at Abia State University Teaching Hospital, Aba, Nigeria
}

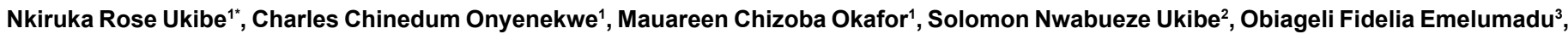
Aloysius Ngozi Okpogba ${ }^{4}$ and Obiageli Onyema-lloh ${ }^{5}$

${ }^{1}$ Deparment of Medical Laboratory Science, College of Health Sciences, Nnamdi Azikiwe University, Anambra State, Nigeria

${ }^{2}$ Department of Prosthetics and Orthotics, School of Health Technology, Federal University of Technology Owerri, Imo State, Nigeria

${ }^{3}$ Department of Human Biochemistry, College of Health Sciences, Nnamdi Azikiwe University, Nigeria

${ }^{4}$ Department of Community Medicine, College of Health Sciences, Nnamdi Azikiwe University, Nnewi, Anambra State, Nigeria

${ }^{5}$ Deparment of Chemical Pathology, College of Health Sciences, Nnamdi Azikiwe University, Anambra State, Nigeria

\begin{abstract}
Background: Contraceptives are devices or techniques that permit sexual union without resultant pregnancy. Women on different contraceptive methods have been linked with the development of various diseases including changes in serum trace element levels. Therefore, the relationship between contraceptive use and trace elements needs to be investigated. This was a cohort study designed to determine the possible variations in serum concentrations of lead, copper, zinc and selenium in women practicing different contraceptive methods and attending family planning clinic at Abia State University Teaching Hospital, Aba, Southeast, Nigeria.
\end{abstract}

Methods: Two hundred and forty (240) women within their reproductive age of 18-45 years were recruited for the study. sixty (60) women were on implants, sixty (60) were on intra uterine contraceptive device (IUCD) while sixty (60) were on combined oral contraceptive pills (COCP), the remaining sixty (60) women who were not on any contraceptive methods were recruited among the staff of the hospital and used as control group. $5 \mathrm{ml}$ of venous blood sample was collected and dispensed into plain containers. Serum was processed and stored at $-20^{\circ} \mathrm{C}$ until assayed for lead, copper, selenium and zinc using atomic absorption spectrophotometer (AAS).

Results: The result shows that the mean serum level of copper was significantly higher in women on all the contraceptive methods (Implants, IUCD and COCP) when compared with control group ( $<<0.05$ respectively). However, the mean serum levels of selenium and zinc were significantly lower in women on different contraceptive methods when compared with control group ( $p<0.05$ respectively). The mean serum copper $(\mathrm{mg} / \mathrm{dl})$ in women on implant and IUCD were significantly higher when compared with women on COCP ( $p<0.05$ in each case) and significantly lower in implant than IUCD participants $(p<0.05)$. The mean serum level of zinc $(\mathrm{mg} / \mathrm{dl})$ was significantly higher in women on COCP and IUCD compared with women on implant and significantly lower in COCP compared with women on IUCD ( $p<0.05$ in each case). The mean serum level of selenium in women on COCP was significantly higher compared with women on implant and IUCD $(p<0.05)$ and significantly lower in participants on implants than those on IUCD $(p<0.05)$.

Conclusion: The present study established a significant reduction in trace elements degrees suggesting possible deficiency of these minerals while significantly higher level of copper observed in women on all the contraceptive methods suggests potential risk of cardiovascular problems and oxidative stress in the affected women. It is therefore suggested that routine assessment of trace elements be recommended for women practicing various contraceptive methods in order to improve their quality of lives and easy management.

Keywords: Lead; Trace elements; Women; Contraceptives; Nigerias

\section{Introduction}

Contraceptive devices, have played a very important role in birth control over the past few decades, Contraceptives are devices or techniques that permit sexual union without resultant pregnancy [1]. There has been interest in recent years about alterations in various metabolic processes and trace element profile associated with the use of contraceptives. Alterations in metabolic processes and trace element profiles are governed by genetic disposition and environmental factors. Changes in life style, environmental factors, dietary habits and active ingredients of hormonal agent have been known to affect status of trace elements in human. For instance contraceptives (compounds with oestrogen-progestrogen-like actions) have been used by women in Nigeria to control fertility and as such have been shown to interfere with the absorption of some micro nutrients such as trace elements and vitamins [2]. Possible changes in serum trace elements and vitamins of women on contraceptives have been postulated [3]. Changes in the tissue level or bioavailability of these elements could play a significant role in the health risk and pathogenesis of some disorders such as cardiovascular complications, the ageing process and certain cancers

*Corresponding author: Nkiruka Rose Ukibe, Deparment of Medical Laboratory Science, College of Health Sciences, Nnamdi Azikiwe University, Nnewi Campus, Anambra State, Nigeria, Tel: +2348062915510; E-mail: nr.ukibe@unizik.edu.ng, ezinne4real2007@yahoo.com

Received August 01, 2017; Accepted August 18, 2017; Published August 25 , 2017

Citation: Ukibe NR, Onyenekwe CC, Okafor MC, Ukibe SN, Emelumadu OF, et al., et al. (2017) Variations in Serum Concentrations of Lead, Copper, Zinc and Selenium in Women Practicing Different Contraceptive Methods at Abia State University Teaching Hospital, Aba, Nigeria. J Bioanal Biomed 9: 212-216. doi:10.4172/1948-593X.1000180

Copyright: @ 2017 Ukibe NR, et al. This is an open-access article distributed under the terms of the Creative Commons Attribution License, which permits unrestricted use, distribution, and reproduction in any medium, provided the original author and source are credited. 
Citation: Ukibe NR, Onyenekwe CC, Okafor MC, Ukibe SN, Emelumadu OF, et al. (2017) Variations in Serum Concentrations of Lead, Copper, Zinc and Selenium in Women Practicing Different Contraceptive Methods at Abia State University Teaching Hospital, Aba, Nigeria. J Bioanal Biomed 9: 212-216. doi:10.4172/1948-593X.1000180

have been associated with the use of contraceptives [4]. Some of these trace elements, for example zinc, selenium and manganese, are potent antioxidants known to be involved in preventing free radical induced damage. These antioxidants are involved in preventing the formation of free radicals-induced damage, scavenging them or promoting free radical decomposition in the body [5]. Zinc and copper have been shown to boost immune response and their importance in the malnourished persons has been documented $[5,6]$.

There are potentially toxic elements with possible essential functions in low doses including lead, cadmium, mercury, arsenic, lithium, tin, aluminium [7]. Although these trace elements constitute a relatively small amount of the total body tissues, they are essential for many vital processes. The acceptable limit for trace element has been described $\mathrm{Cu}$, zinc, selenium and lead as (4.2-5.0 $\mu \mathrm{g} / \mathrm{l}, 0.005-0.086 \mu \mathrm{g} / \mathrm{l}$, 2.1-30.9 $\mu \mathrm{g} / \mathrm{l}$ and 12-27 $\mu \mathrm{g} / \mathrm{l}$ respectively) [8]. The biological role of trace elements, especially copper, zinc and selenium are accepted as essential for optimal human health, because of their diverse well-documented metabolic functions. They have catalytic, structural and regulatory roles and interact with macromolecules such as enzymes, hormones and other biological molecules [9]. Zinc is a component of more than 200 different enzyme system functions that are included in most events such as immunity and cell division $[6,10]$. Zinc is a co-factor for the antioxidant enzyme Superoxide Dismutase (SOD) and also involved in carbohydrate and protein metabolism [11]. Zinc deficiency affects host defence in a variety of ways. It results in decreased phagocytes and leads to reduced numbers of circulating T-cells [12]. Copper is an essential trace element involved in the metabolism of several key enzymes including cytochrome oxidase of the mitochondrial electron transport and cytosolic superoxide dismutase [13]. Moreover, $60 \%$ of copper in the blood is tightly bounded to a Copper-Zinc dependent enzyme known as superoxide dismutase $(\mathrm{Cu} / \mathrm{Zn} / \mathrm{SOD})$ which is a powerful antioxidant [14]. Trace elements have long been suggested to be the missing link in atherosclerosis, osteoporosis and hypertension [15]. Se, $\mathrm{Cu}$ and $\mathrm{Zn}$ have antioxidant properties and theoretically protect the body from cardiovascular diseases [16]. Therefore, their alterations may play a role in atherosclerosis and hypertension. $\mathrm{Cu}$ deficiency has also been observed in the early stages of osteoporosis [17] and copper increase has been implicated in cardiovascular risks in women practicing some of these contraceptives [18]. Various studies have documented the relationship amid trace elements and contraceptive use, bringing to light some of the mechanisms by which contraceptives influence these parameters [18]. The study therefore aimed to investigate the possible alterations and the effects of various contraceptive methods on the levels of trace elements ( $\mathrm{Se}, \mathrm{Cu}$ and $\mathrm{Zn}$ ) in women practicing them at family planning clinic Abia state University Teaching Hospital, Aba, Nigeria.

\section{Materials and Methods}

\section{Study design}

This was a cohort study (prospective observational study) designed to determine the variation in concentrations of Lead, zinc, copper, selenium in women on different contraceptive methods attending family planning clinic at Abia State University Teaching Hospital Aba, Abia State, Nigeria.

\section{Study population}

This was a cohort study conducted on non-lactating, non-pregnant women who were on different contraceptive methods for at least a period of twelve months and were attending family clinic unit at Abia
State Teaching Hospital Aba, using random sampling technique. A total of two hundred and forty (240) women within reproductive age (18-45) years participated in the study. Sixty (60) of these women were on combined oral contraceptive (20-50 $\mu \mathrm{g} / \mathrm{l}$ Estrogen and Progestin) (COCP), sixty (60) were on implants (Norplant, jadelle and implanon) and sixty (60) on intra uterine contraceptive device (IUCD). The remaining sixty (60) non-lactating, non-pregnant women within the same reproductive age who were not on any contraceptive method were recruited among the hospital staff and used as control group.

\section{Place of study}

The study was carried out at family planning clinic unit of Abia State University Teaching Hospital Aba.

\section{Inclusion criteria}

Women within their reproductive age (18-45) were recruited for the study and non-lactating and non-pregnant women were recruited. Only women who have been on contraception for not less than twelve months were recruited for the study while women who are not on any contraceptive were used as the control group.

\section{Exclusion criteria}

Women suffering from chronic diseases like cancer, diabetes and hypertension were excluded from the study. Pregnant and breast feeding mothers were also excluded from the study. Women who were on any dietary supplementation prior to the study were excluded and female smokers and drinkers were also excluded from the study.

Sample collection: Five millilitres of venous blood was collected from the participants by aseptic procedure in the sitting position and pushed slowly into acidified disposable tubes prepared in line with the guidelines for sample collection for trace elements as described by Ref. [19]. The blood was spun at 3000 revolutions per minute for five minutes to obtain serum. Serum from both participants and control group were immediately stored at $20^{\circ} \mathrm{C}$ till analysis was done. A wellstructured questionnaire was given to each participant to obtain information of their socio-demographic profile, personal bio-data and their health status.

\section{Methods}

Determination of serum lead, copper, selenium and zinc: Determinations of lead, copper, selenium and zinc in serum analysis were conducted using Varian AA240 Atomic Absorption Spectrophotometer according to the method of APHA 1995 (American Public Health Association).

Working principle: Atomic absorption spectrophotometer's working principle is based on the sample being aspirated into the flame and atomized when the AAS's light beam is directed through the flame into the monochrometer, and onto the detector that measures the amount of light absorb by the atomized element in the flame. Since metals have their own characteristic absorption wavelength, a source lamp composed of that element is used, making the method relatively free from spectral or radiational interferences. The amount of energy of the characteristic wavelength absorbed in the flame is proportional to the concentration of the element in the sample.

Procedure: A series of standard metal solutions in the optimum concentration range was prepared, the reference solutions were prepared daily by diluting the single stock element solutions with water containing $1.5 \mathrm{ml}$ concentrated nitric acid/liter. A calibration blank was prepared using all the reagents except for the metal stock 
Citation: Ukibe NR, Onyenekwe CC, Okafor MC, Ukibe SN, Emelumadu OF, et al. (2017) Variations in Serum Concentrations of Lead, Copper, Zinc and Selenium in Women Practicing Different Contraceptive Methods at Abia State University Teaching Hospital, Aba, Nigeria. J Bioanal Biomed 9: 212-216. doi:10.4172/1948-593X.1000180

solutions. Calibration curve for each metal was prepared by plotting the absorbance of standards versus their concentrations.

\section{Statistical analysis}

The results were expressed as mean \pm SD. Statistical analysis were performed on data using statistical package for social science version 20.0 software applications. Student's t-test was used to determine the significant difference between the mean values with $\mathrm{p}$ value set at $\mathrm{p}<0.05$. Comparison of clinical characteristics and biochemical parameters of cases with control groups was performed using one way ANOVA. Pearson product moment correlation was used to determine association between the various parameters

\section{Results}

\section{Serum levels of lead, copper, selenium, and zinc in all test} groups and control group

The result shows that the mean $( \pm \mathrm{SD})$ Age and BMI $\left(\mathrm{kg} / \mathrm{m}^{2}\right)$ of women on all the contraceptives $(29.94 \pm 5.46,27.90 \pm 5.08)$ were not significantly different when compared with control participants (30.37 $\pm 6.24,27.59 \pm 2.69)(p>0.05$ respectively). However, the mean $( \pm$ $\mathrm{SD})$ serum level of copper $(\mathrm{mg} / \mathrm{dl})$ in women on all the contraceptive methods $(0.20 \pm 0.10)$ was significantly higher when compared to control group $(0.01 \pm 0.01)(\mathrm{p}<0.05$ respectively). There was no significant difference in serum lead level in women on all the contraceptive methods $(2.37 \pm 3.25)$ when compared to control group $(2.27 \pm 2.12)$ ( $>0.05)$. Contrastingly, the mean serum level of selenium $(\mu \mathrm{g} / \mathrm{L})$ was significantly lower in women on all the contraceptive methods $(2.00 \pm$ $0.94)$ when compared to control group $(4.56 \pm 0.75)(p<0.05)$. Similarly, the mean serum level of zinc $(\mathrm{mg} / \mathrm{dl})$ was significantly lower in women on all the contraceptive methods $(3.93 \pm 2.70)$ when compared to control group $(5.76 \pm 2.94)(\mathrm{p}<0.05)$ (Table 1).

Comparison of serum levels of lead, copper, selenium, and zinc in women on different contraceptive methods and control group

The result shows that the mean $( \pm \mathrm{SD})$ serum level of copper $(\mathrm{mg} /$ $\mathrm{dl})$ in women on COCP, implant and IUCD $(0.04 \pm 0.03,0.24 \pm 0.05$, $0.27 \pm 0.06)$ were significantly higher when compared with control group $(0.01 \pm 0.01)(\mathrm{p}<0.05$ respectively). The mean $( \pm \mathrm{SD})$ serum level of copper $(\mathrm{mg} / \mathrm{dl})$ in women on implant $(0.24 \pm 0.05)$ and IUCD $(0.27 \pm 0.06)$ were significantly higher when compared with women on COCP $(0.04 \pm 0.03)(\mathrm{p}<0.05$ in each case). The mean serum level of copper in women on implant $(0.24 \pm 0.05)$ was significantly lower when compared to women on IUCD $(0.27 \pm 0.06)(\mathrm{p}<0.05)$.

The mean serum level of zinc $(\mathrm{mg} / \mathrm{dl})$ in women on COCP $(4.70 \pm$ $2.44)$, IUCD $(4.90 \pm 2.76)$ and implant $(0.56 \pm 0.16)$ were significantly lower when compared with control group $(5.76 \pm 2.94)(\mathrm{p}<0.05$ respectively).

\begin{tabular}{|c|c|c|c|c|}
\hline \multirow{2}{*}{ Parameters } & \multicolumn{2}{|c|}{ Groups } & \multirow{2}{*}{-value } & \multirow{2}{*}{ P-value } \\
\cline { 2 - 3 } & Study Group $(\mathbf{n}=\mathbf{1 8 0})$ & Control $(\mathbf{n}=\mathbf{6 0})$ & & \\
\hline Age $($ years $)$ & $29.94 \pm 5.46$ & $30.37 \pm 6.24$ & 0.237 & 0.75 \\
\hline BMI $\left(\mathrm{kg} / \mathrm{m}^{2}\right)$ & $27.90 \pm 5.08$ & $27.59 \pm 2.69$ & 0.281 & 0.501 \\
\hline Copper $(\mathrm{mg} / \mathrm{dl})$ & $0.20 \pm 0.10$ & $0.010 \pm 0.006$ & 19.353 & $0.000^{*}$ \\
\hline Lead $(\mu \mathrm{\mu g} / \mathrm{L})$ & $2.37 \pm 3.25$ & $2.27 \pm 2.12$ & 0.282 & 0.778 \\
\hline Selenium $(\mu \mathrm{g} / \mathrm{L})$ & $2.00 \pm 0.74$ & $4.56 \pm 0.95$ & -23.286 & $0.000^{*}$ \\
\hline Zinc $(\mathrm{mg} / \mathrm{dl})$ & $3.93 \pm 2.42$ & $5.76 \pm 2.94$ & -5.313 & $0.000^{*}$ \\
\hline
\end{tabular}

Table 1: Mean $( \pm S D)$ of serum levels of lead, copper, selenium and zinc in all test groups and control group.
The mean serum level of zinc $(\mathrm{mg} / \mathrm{dl})$ in women on COCP $(4.70 \pm$ $2.44)$ and IUCD $(4.90 \pm 2.76)$ were significantly higher when compared with women on implant $(0.56 \pm 0.16)(\mathrm{p}<0.05$ respectively $)$ and significantly lower in women on COCP $(4.70 \pm 2.44)$ compared with women on IUCD $(4.90 \pm 2.76)(\mathrm{p}<0.05)$.

The mean serum level of selenium $(\mu \mathrm{g} / \mathrm{L})$ in women on all the different types of contraceptive COCP, implant and IUCD $(2.79 \pm 0.75$, $1.29 \pm 0.59,2.64 \pm 0.48)$ were significantly lower when compared to control group $(4.56 \pm 0.75)(\mathrm{p}<0.05$ respectively). The mean serum level of selenium in women on COCP $(2.79 \pm 0.75)$ was significantly higher when compared to women on implant $(1.29 \pm 0.59)$ and IUCD $(2.64 \pm 0.48)(\mathrm{p}<0.05)$. The mean serum level of selenium in women on implant $(1.29 \pm 0.59)$ was significantly lower when compared to women on IUCD $(2.64 \pm 0.48)(\mathrm{p}<0.05)$.

The mean serum level of lead $(\mu \mathrm{g} / \mathrm{L})$ was not significantly different in women on COCP $(2.04 \pm 1.77)$, implant $(2.04 \pm 0.03)$ and IUCD $(2.36 \pm 1.76)$ when compared with control group $(2.27 \pm 2.12)$ ( $\mathrm{p}>0.05$ respectively). Similarly, there was no significant difference observed when compared between women on different types of contraceptives methods ( $>0.05)$ (Table 2).

There was significant negative correlation between copper and age $(\mathrm{r}=-0271, \mathrm{p}<0.05)$. Selenium and zinc were significantly negatively correlated with BMI $(r=-0.205, \mathrm{p}<0.05, \mathrm{r}=0.253, \mathrm{p}<0.05)$ but significantly positively correlated with age $(\mathrm{r}=0.373, \mathrm{P}<0.05, \mathrm{r}=0.294$, $\mathrm{P}<0.05$ respectively).

\section{Discussion}

The present study shows that the mean serum copper $(\mathrm{mg} / \mathrm{dl})$ concentrations in women on all the contraceptive methods were significantly higher when compared with control participants. However, the serum level of copper $(\mathrm{mg} / \mathrm{dl})$ in women on implant and IUCD were significantly higher when compared with women on COCP and significantly lower in women on implant when compared with women on IUCD. Studies have reported that contraceptives are associated with increased serum copper level [20-22]. Pincemail and colleagues reported that a woman having a plastic T-shaped frame wrapped with cooper band presented a plasma copper value that remained within the normal range [23]. The previous authors indicated that the estrogen level in the oral contraceptives is responsible for increased copper and ceruloplasmin synthesis in the liver which leads to an increase in serum copper levels. Excess level of circulating copper may have adverse effect on liver which may lead to hepatolenticular degeneration

\begin{tabular}{|c|c|c|c|c|}
\hline \multirow{2}{*}{ Groups } & \multicolumn{4}{|c|}{ Parameters } \\
\cline { 2 - 5 } & Copper $(\mathbf{m g} / \mathbf{d l})$ & Lead $(\boldsymbol{\mu g} / \mathbf{l})$ & Selenium $(\boldsymbol{\mu g} / \mathbf{l})$ & Zinc $(\mathbf{m g} / \mathbf{d l})$ \\
\hline COCP $(\mathrm{A})(\mathrm{n}=60)$ & $0.04 \pm 0.03$ & $2.04 \pm 1.77$ & $2.79 \pm 0.75$ & $4.70 \pm 2.44$ \\
\hline Implant (B) (60) & $0.24 \pm 0.05$ & $2.04 \pm 0.03$ & $1.29 \pm 0.59$ & $0.56 \pm 0.16$ \\
\hline IUCD (C) $(\mathrm{n}=60)$ & $0.27 \pm 0.06$ & $2.36 \pm 1.76$ & $2.64 \pm 0.48$ & $4.90 \pm 2.76$ \\
\hline Control (D) (n=60) & $0.010 \pm 0.006$ & $2.27 \pm 2.12$ & $4.56 \pm 0.75$ & $5.76 \pm 2.94$ \\
\hline F-value & 707.09 & 17.034 & 317.216 & 73.28 \\
\hline P-value & $0.000^{*}$ & 0.072 & $0.000^{*}$ & $0.000^{*}$ \\
\hline POST HOC & - & - & - & - \\
\hline AvsB & $0.000^{*}$ & 0.741 & $0.000^{*}$ & $0.000^{*}$ \\
\hline AvsC & $0.000^{*}$ & 0.28 & 0.399 & 0.117 \\
\hline AvsD & $0.000^{*}$ & 0.532 & $0.000^{*}$ & $0.000^{*}$ \\
\hline BvsC & $0.000^{*}$ & 0.346 & $0.000^{*}$ & $0.000^{*}$ \\
\hline BvsD & $0.000^{*}$ & 0.211 & $0.000^{*}$ & $0.000^{*}$ \\
\hline CvsD & $0.000^{*}$ & 0.782 & $0.000^{*}$ & 0.574 \\
\hline
\end{tabular}

Table 2: Comparison of mean ( \pm SD) serum levels of lead, copper, selenium and zinc in women on different contraceptive methods and control group. 
Citation: Ukibe NR, Onyenekwe CC, Okafor MC, Ukibe SN, Emelumadu OF, et al. (2017) Variations in Serum Concentrations of Lead, Copper, Zinc and Selenium in Women Practicing Different Contraceptive Methods at Abia State University Teaching Hospital, Aba, Nigeria. J Bioanal Biomed 9: 212-216. doi:10.4172/1948-593X.1000180

[24]. Since the introduction of contraceptives, many side effects have been reported. Among the documented effects of contraceptives are elevations in serum level of copper [25-28]. Pincemail et al. [23] in their study further reported a mean plasma copper level as higher as $1.5 \mathrm{mg} / \mathrm{l}$. It has been reported that estrogen-containing preparations was the cause of an increase in specific set of acute-phase proteins elaborated by the liver $[29,30]$. It is also postulated that copper may have a pro oxidant effect that would increase cardiovascular disease [31,32]. Previous studies reported that an increased copper concentration is the major event that leads to increased lipid peroxides [33,23]. However, it is suggested that oral contraceptive containing $<50 \mu \mathrm{g}$ of estrogen and a second or third generation progestin may be reasonably safe from a cardiovascular point of view $[34,35]$.

In the present study serum zinc level was significantly lower in women on different contraceptives when compared with control group. The reduction was more in women on implant compared with other contraceptives. Previous studies have reported lower levels of zinc in individuals on oral contraceptives and implants [36,37]. The reason for this reduction in zinc levels is not well known but it may be attributed to redistribution of blood zinc with resultant increase in erythrocyte zinc as result of oral contraceptive use [24]. This reduced zinc level may also be due to increased serum copper level. Decrease in serum zinc levels are reported to result not only in increased platelet aggregation but may also increase serotonin release [38]. The incidence of venous thrombus in combination pill users is known to be very high than in the control group. As a whole, contraceptive may alter the post absorptive utilization of zinc. Circulating zinc level may be reduced while some tissue level may be increased. Also the release of zinc from tissue may be depressed in oral contraceptive users. However, Pincemail et al. [23] in their study have reported increased level of zinc compared with their control counterparts. The authors attributed this to overexpression of antioxidant metallothioneins and inhibition of copper induced free radical species and the cut off point for discriminating Oral Contraceptives Users (OCU) from all non-contraceptive users (NCU+IUD) was 2.1 for copper/zinc. It is therefore suggested that this changes may alter dietary zinc requirement.

Furthermore, the mean serum level of selenium $(\mu \mathrm{g} / \mathrm{L})$ in women on all the different types of contraceptives (COCP, implant and IUCD) were significantly lower when compared with control group. Study has reported significant reduction in serum selenium level of women on combined oral contraceptive [39]. There seems to be a mechanism induced by the components of oral contraceptive which interfere with the absorption of selenium [2,40]. Similarly, Pincemail et al. [23] reported a significant reduction in serum selenium level among two hundred female students placed on oral contraceptives for a period of eighteen months. Previous studies also reported that selenium concentration was significantly higher in oral contraceptives than those of NCU and IUD [23]. The authors explained that the use of combined oral contraceptive ( $20 \mu \mathrm{g}$ ethinylestradiol and $150 \mu \mathrm{g}$ desogestin) led to a significant increase of glutathione reductase, a selenium dependent

\begin{tabular}{|c|c|c|c|c|}
\hline & AGE & BMI & LMP & DURATION \\
\hline Copper $(\mathrm{mg} / \mathrm{dl})$ & $-0.271 ; p<0.05$ & $0.126 ; p>0.05$ & $-0.177 ; p>0.05$ & $-0.089 ; p>0.05$ \\
\hline Lead $(\mu \mathrm{g} / \mathrm{l})$ & $0.188 ; p>0.05$ & $-0.118 ; p>0.05$ & $-0.105 ; p>0.05$ & $-0.157 ; p>0.05$ \\
\hline Selenium $(\mu \mathrm{g} / \mathrm{l})$ & $0.373 ; p<0.05$ & $-0.205 ; p<0.05$ & $0.058 ; p>0.05$ & $-0.107 ; p>0.05$ \\
\hline Zinc $(\mathrm{mg} / \mathrm{dl})$ & $0.294 ; p<0.05$ & $-0.253 ; p<0.05$ & $-0.135 ; p>0.05$ & $-0.019 ; p>0.05$ \\
\hline
\end{tabular}

Table 3: Correlation of lead, copper, selenium and zinc with age, body mass index, last menstrual period and duration of contraceptive in test group. enzyme assuming the elimination of lipid peroxides. Such differences in selenium status however, was said to vary with circulating estrogen concentration in reproductive age women $[23,41]$.

The mean serum level of lead $(\mu \mathrm{g} / \mathrm{L})$ was not significantly different in women on COCP, implant and IUCD when compared with control group. Serum lead level was not affected by contraceptives. This was similar with the findings observed by some authors $[40,42]$. Hesse and colleagues reported that serum lead level was not affected by oral contraceptives while the later reported that serum lead levels were similar in participants and control groups. We can therefore say that the absorption, distribution and metabolism of lead are independent on the use of oral contraceptive (Table 3).

\section{Conclusion}

In conclusion, this study established that there were significant alterations in the levels of trace elements in women on different contraceptives compared with control group. Concentrations of zinc and selenium were significantly lower while serum level of copper was significantly higher in all the study groups compared with controls suggesting mineral deficiency and high potentials for cardiovascular problems and oxidative stress. Routine trace element investigations and adequate mineral supplementation should therefore be recommended for women on all kinds of contraceptive use. Additionally, users should avoid contraceptives with high contents of estrogen.

\section{Consent}

All authors hereby declare that all written informed consent was obtained from all the patients who participated in this study.

\section{Ethical Approval}

All author(s) hereby declare that all experiment and procedure have been examined and approved by the appropriate board of ethics committee of Abia State University Teaching Hospital Aba, South East Nigeria, and research have therefore been performed in accordance with the standards laid down in the 1964 Declaration of Helsinki.

\section{Competing Interests}

Authors have declared that no competing interests exist

\section{Funding Source}

There is no funding source for the study.

\section{References}

1. Hatcher RA, Trussell J, Nelson A (2004) Depo-Provera injections, implants, and progestin-only pills (minipills). Contraceptive Technology (1 $18^{\text {th }}$ edn.). Irvington Publishers, NY, USA.

2. Fallah S, Sani FV, Firoozrai M (2009) Effect of contraceptive pill on the selenium and zinc status of healthy subjects. Contraception 80: 40-43

3. Berg G, Kohlmeier L, Brenner H (1997) Use of oral contraceptives and serum beta-carotene. Eur J Clin Nutr 51: 181-187.

4. Olaniyan DA, Taylor S (2010) Vitamin and antioxidant: The body fluid is not water. Nig Med J 16: 20-31.

5. Young IS, Woodside JV (2010) Antioxidants in health and diseases. J Clin Pathol 54: 176-186.

6. Ukibe NR, Onyenekwe CC, Ahaneku JE, Ukibe SN, Meludu SC, et al. (2013) Evaluation of nutritional status of HIV infected females during menstrual cycle in Nnewi, South Eastern Nigeria. Sci J Med Sci 2: 161-168.

7. Agget RJ, Devis NT (1983) Some nutritional aspect of trace metals. J Inherent Metab Dis 6: 22-30.

8. Minoia C, Sabbioni E, Apostoli P, Pietra R, Pozzoli L, et al. (1990) Trace element 
Citation: Ukibe NR, Onyenekwe CC, Okafor MC, Ukibe SN, Emelumadu OF, et al. (2017) Variations in Serum Concentrations of Lead, Copper, Zinc and Selenium in Women Practicing Different Contraceptive Methods at Abia State University Teaching Hospital, Aba, Nigeria. J Bioanal Biomed 9: 212-216. doi:10.4172/1948-593X.1000180

reference values in tissues from inhabitants of the European Community 1. A study of 46 elements in urine, blood and serum of Italian subjects. Sci Total Environ 95: 89-105.

9. Naser HK, Mansi M, Barqawi T, Aburjai (2009) Copper and zinc status in Jordanian patients with $12-$ Thalassemia major treated with deferoxamine. Res Bio Sci pp: 566-572.

10. Tudor RP, Zalewski RN, Ratnaike (2005) Zinc in health and chronic disease. J Nutr Health Aging 9: 45-51.

11. Al-Numair K (2006) Copper and zinc status in healthy volunteers living in Saud Arabia. J Med Sci 6: 519-527.

12. Karyadi E, West CE, Schultink W, Ronald RH, Gross R, et al. (2002) A double blind, placebo-controlled study of vitamin Aand zinc supplementation in persons with tuberculosis in Indonesia: effects on clinical response and nutritional status. Am J Clin Nutr 75: 720-727.

13. Adewumi MT, Njoku CH, Saidu Y, Abubakar MK, Shehu RA (2007) Serum chromium, copper and manganese levels of diabetic subjects in katsina Nigeria. Asian J Biochem 2: 284-288.

14. Maybauer MO, Maybauer DN, Herndon DL, Traber (2006) the role of superoxide dismutase in systemic inflammation. Shock. 5: 212-207.

15. Nielsen FH (1993) Ultratrace elements of possible importance for human health: An update progress. Clin Bio Res 380: 355-376.

16. Willett W (1983) Prediagnostic serum selenium and risk of cancer. The Lance 322: 130-134.

17. Underwood E (2012) Trace elements in human and animal nutrition ( $5^{\text {th }}$ edn.). Academic Press, Elsevier.

18. Akinloye O (2011) Effects of contraceptives on serum trace elements, calcium and phosphorus levels. West Indian Med J 60: 308-315.

19. Cornelis R, Heinzow B, Herber RF, Christensen JM, Poulsen OM, et al. (1996) Sample collection guidelines for trace elements in blood and urine. J Trace Elem Med Biol 10: 103-127.

20. Prasad AS, Oberleas D, Moghissi KS, Ley KY, Stryker JC (1975) Effect of ora contraceptive agents on nutrients: I minerals. Am J Clin Nutr 28: 377-384.

21. Chilvers DC, Jones MM, Selby PL, Dawson JB, Hodgkinson A (1985) Effect of oral ethinyl oestradiol and norethisterone on plasma copper and zinc complexes in post-menopausal women. Horm Metab Res 17: 532-535.

22. Berg G, Kohlmeier L, Brenner H (1998) Effect of oral contraceptive progestins on serum copper concentration. Eur J Clin Nutr 52: 711-715.

23. Pincemail J, Vanbelle S, Gaspard U, Collette G, Haleng (2007) Effect of different contraceptive methods on the oxidative stress status in women aged 40-48 years from the ELAN study in the province of Lie'ge, Belgium. Hum Reprod 01-09.

24. Crews MG, Taper IJ, Ritchey SJ (1980) Effects of oral contraceptives on zinc and copper balance in young women. Am J Clin Nutr. 33: 1940-1945.

25. Liukko P, Erkkola P, Pakannen S, Jarnstrom V, Nanto H (2005) Trace elements during 2 years oral contraception with low-oestrogen preparations. Gyn Obst Invest 25: 113-117.
26. Berg G, Kohlmeier I, Branner H (1998) Effect of oral contraceptive progestin on serum copper concentration. Eur J Clin Nutr 52: 711-715

27. Imani GDN, Marceline PMJ, Bertrand FK (2012) Iron status of malaria patients in Cameroon. J Nutr 7: 620-624.

28. Barbic BH, Bastos M, Rosendaal BH, Hylckama V (2013) Different combined oral contraceptives and the risk of venous thrombosis: systematic review and network meta-analysis. BMJ 6: 200-205.

29. Limpongsanurak S, Jenkins N, Fotherby K (1981) Effect of contraceptive steroids on serum levels of sex hormone binding globulin and caerulopasmin. Curr Med Res Opin 7: 185-191

30. Kluft C, Leuven JA, Helmerhorst FM, Krans HM (2002) Pro-inflammatory effects of estrogens during use of oral contraceptives and hormone replacement therapy. Vascul Pharmacol 39: 149-154

31. Wu T, Sempos CT, Freudenheim JL, Muti P, Smit E (2004) Serum iron, copper and zinc concentrations and risk of cancer mortality in US adults. Ann Epidemio 14: 195-201.

32. Leone N, Courbon D, Ducimetiere P, Zureik M (2006) Zinc, copper, and magnesium and risks for all cause cancer, and cardiovascular mortality Epidemiol 17: 308-314.

33. Mezzetti A, Pierdomenico SD, Costantini F, Romano F, De Cesare D (1998) Copper/zinc ratio and systemic oxidant load: effect of aging and aging-related degenerative diseases. Free Rad Biol Med 25: 676-681.

34. Carr BR, Ory H (1997) Estrogen and progestin components of ora contraceptives: relationship to vascular disease. Contraception 55: 267-272.

35. Rosenberg L, Palmer JR, Sands MI, Grimes D, Bergman U (1997) Modern oral contraceptives and cardiovascular diseases. Am J Obstet Gynecol 177 707-715.

36. Ynsa MD, Ager FJ, Millan JC, Gomez-Zubelbia MA, Pinheiro T (2004) Effect of hormone replacement therapy on the elemental contents of uterine tissue. Biol Trace Elem Res 101: 37-46.

37. Holt GA (1998) Food and drug interactions. Precept Press, Chicago, USA pp: 197-198.

38. Poller I, Thompson JM, Thomas W (2011) Estrogen/Progestogen ora contraception and blood clotting. Br Med J 32: 23-29.

39. Bush Al (2003) The metallobiology of Alzheimer's disease. Trends Neurosc 26: 207-214.

40. Hesse HD, Lawrence MA, Dempster WS, Pocock F (1988) Reference concentrations of serum selenium and manganese in healthy nulliparas. South Afr Med J 73: 163-165.

41. Massafra C, Buonocore G, Berni S, Gioia D, Giuliani A (1993) Antioxidant erythrocyte enzyme activities during oral contraception. Contraception 47: 591 596.

42. Sakinloye O, Adebayo TO, Oguntibeju OO, Oparinde DP, Ogunyemi EO (2011) Effects of contraceptives on serum trace elements, calcium and phosphorus levels. West Ind Med J 60: 308-315. 